\title{
CONNECTION BETWEEN SIMILARITY AND ESTIMATION RESULTS OF PROPERTY VALUES OBTAINED BY STATISTICAL METHODS
}

\author{
Jacek Zyga, PhD \\ Faculty of Engineering and Architecture, \\ Lublin University of Technology, \\ e-mail:j.zyga@pollub.pl
}

\section{Abstract}

The article discusses the topic of the application range of statistical methods in estimating property value on the grounds of a comparative approach. The analysis of application effects to estimate the unitary value of properties, respectively similar and dissimilar sets of market properties, by using the method of least squares and a linear price model. The prepared test set was developed from a priori assumed explanatory variable values as well as deterministically specified dependent variables (simulated prices) which were subjected to additional modification by a random factor. On the basis of the prepared set and series of accounting experiments, the estimation effects of any property out of a tested set were analyzed, understood as the determination of the value of the function of explanatory variables in the way of extrapolation or interpolation of values describing these variables. The experiments carried out show that the estimation of an explanatory variable for a random property out of a set of elements serving as the estimation base can be reliable only when it is related to the interpolation in the set of explanatory variables of this base. The application as an estimation base - a set in relation to which explanatory variables of the estimated property exceed the limits of corresponding variables, requires the completion of a basic set with records describing properties similar or close to the estimated property so that the values of explanatory variables for the estimated property are contained in the appropriate subsections of values of corresponding explanatory variables of the basic set.

The paper refers to the issue of defining property market value indicating, by the prism of conducted experiments, that the estimation results obtained by means of statistical methods do not always meet the requirements of the statutory definition of market value, and hear rather in the direction of a result corresponding to the so-called "desk appraisal" result.

Keywords: similarity, data models, data selection.

JEL Classification: R15, C15, C51.

Citation: Zyga J., 2016, Connection Between Similarity and Estimation Results of Property Values Obtained by Statistical Methods, Real Estate Management and Valuation, Vol. 24, No. 3, pp. 5-15.

DOI: $10.1515 /$ remav-2016-0017

\section{Introduction}

The use of statistical methods in property appraisal seems to be an intrinsic part of the tool set used by appraisers. Statistical methods are included in the recommended procedures applied for property valuation, present in both Polish as well as European and international standards of real estate appraisal. They are applied all over the world, in many contexts and under many circumstances. Therefore, their presence cannot and should not be undermined. However, the cases of the abuse or improper use of these methods cannot be disregarded. Their complexity and, generally speaking, poorly propagated deep knowledge of them (and in the case of potential recipients of valuations, their frequent lack of basic knowledge), allow for what are not fully professional actions, by which the 
valuer, under the cover of complicated calculations and difficult jargon, can arrive at conclusions based on false premises.

In Polish legal circumstances, formulated mainly in the Real Estate Economy Act., applying statistical methods is treated as a part of the comparative approach ( $\$ 4.2$ ROZPORZĄDZENIE ... 2004). An essential element of this approach is the issue of similarity, the similarity of comparative properties in relation to the object of assessment/valuation, as well as the similarity of comparative properties in relation to each other (ZYGA 2011,2012). In most strictly econometric issues of property evaluation, this problem seems to have been disregarded, not only in the past years (BENJAMIN et al. 2004; BITNER 2004), but nowadays too (BERACHA, BABAJIDE, WiNTOKI 2013; KIEHELÄ, FALKENBACH 2014). Only a few researchers, while analyzing the real estate market statistical model, take the problem of similarity into account (BARAŃSKA 2004; MESZEK 2013).

On one hand, the concept of accounting for the similarities of analyzed elements in analysis restricts the universality of statistical methods included in the range of appraisal procedures. However, such an imposed restriction gives reliability of the valuation results obtained by means of statistical methods. Due to this fact, the present research raises the question of whether the issue of similarity between comparative properties in relation to the valuated property, as well as similarity of comparative properties in relation to each other, influences the results of the value estimation of the property in question, and if so - to what extent.

\section{Description of experiment}

In order to examine the issue of the impact of similarity between the properties constituting the elements of the referential set on the results of the value estimation of random properties, the following detailed problems have been defined:

- the impact of the cohesion of the results of market features of properties in the referential set on standard deviation of the estimation of selected test objects,

- the impact of the degree of dissimilarity between test objects in terms of selected features in relation to property in the referential set on the standard deviation of the estimation of these objects.

The above shown problems were analyzed with the use of test models covering simulated price observations $Y$ (unit prices of hypothetical market objects) together with assumed parameters $X$, related to them by the matrix of explanatory variables $A$. A constant and three elements related to price observations $Y$ by explanatory variables were adopted as the model parameters (included in matrices $A$ ). The values of these variables were determined using basic gradation in even division into three quantities, as shown in Tab. 1:

Set of values of explanatory variables in basic model

Table 1

\begin{tabular}{cccc}
\hline Constant & Variable 1 & Variable 2 & Variable 3 \\
\hline 1 & $2,3,4$ & $2,3,4$ & $1,2,3$ \\
\hline \multicolumn{4}{c}{ Source: own study. }
\end{tabular}

In the alternative variants, every estimation scale was extended by quantities, respectively: "1" as well as " 4,5 " creating the ranges of values shown below.

Set of values of explanatory variables in alternative models

Table 2

\begin{tabular}{cccc}
\hline Constant & Variable 1 & Variable 2 & Variable 3 \\
\hline 1 & $1,2,3,4,5$ & $1,2,3,4,5$ & $1,2,3,4$ \\
\hline
\end{tabular}

Source: own study.

Matrix $A$, presented below, contains the compiled systems of explanatory variables (understood as relations $\boldsymbol{\rho}(\boldsymbol{y}, \boldsymbol{a}), \boldsymbol{\rho}: \boldsymbol{Y} \times \boldsymbol{A} \rightarrow \boldsymbol{X}$, as written by Pawlak (PAWLAK 1983). In an alternative variant, Matrix $\boldsymbol{A} \mathbf{2}$ was built as a Matrix $A 1$ extended by a section corresponding to the description of market elements distinct from (dissimilar to) the elements from set A1. Symbols $a, b, c$ in Tab. 3, in the last section, stand for positions complemented in the alternative versions acc. to the list in Tab. 4. 
Matrix of explanatory variables of test model in a basic variant (VB)

Table 3

\begin{tabular}{cccc}
\hline Constant & Variable 1 & Variable 2 & Variable3 \\
\hline 1 & 2 & 2 & 1 \\
1 & 2 & 3 & 2 \\
1 & 2 & 4 & 3 \\
1 & 3 & 2 & 2 \\
1 & 3 & 3 & 3 \\
1 & 3 & 4 & 1 \\
1 & 4 & 2 & 3 \\
1 & 4 & 3 & 2 \\
1 & 4 & 4 & 1 \\
\hline 1 & $a$ & $b$ & $c$ \\
\hline
\end{tabular}

Source: own study.

Table 4

Variants of explanatory variable matrix completion

\begin{tabular}{cccc}
\hline Alternative variant & $a$ & $b$ & $c$ \\
\hline VA1 & 1 & 1 & 4 \\
VA 2 & 2 & 2 & 4 \\
VA 3 & 3 & 3 & 4 \\
VA 4 & 4 & 4 & 4 \\
VA 5 & 5 & 5 & 4 \\
\hline
\end{tabular}

Source: own study.

Due to the assumption of the full simulation of conditions that could create specific unit prices $Y$, values of parameters $X$ as well as distortions $E$ 1 (basic variant VB) and respectively $E$ 2 (alternative variant VA), shown in Tab. 5, were also assumed as known. Parameters $X$, through linear combinations with independent variables $A$, produce the model values of prices. Simulated prices $\mathrm{Y}$, however, should also take into account random disturbances that have an impact on the prices created on the real market. In the performed simulation, vectors $\boldsymbol{E} 1$ and, respectively, $\boldsymbol{E} 2$ (interpreted as true errors in respect to true values), play the role of these disturbances.

$$
Y=A \cdot X+E
$$

The values of simulated prices - dependent variables $\mathbf{Y} \mathbf{1}$ in basic variant (VB), disturbed by distortions $E \mathbf{1}$ and respectively variables $Y 21, \ldots, Y 25$ in alternative variants (VA), disturbed by distortions $\boldsymbol{E} 2$, have been shown in Tab. 6.

Adopted error values from vectors E1, E2 should obviously aim to reach the value of zero (an expected value) but in the considered case, where the demonstrated data sets (Tab. 3,4$)$ include up to nine/ten records, this condition does not hold true in practice. Therefore, the specific shape (Tab. 5) of disturbance vectors was proposed.

Standard deviations of simulated dependent variables, calculated on the basis of a priori known distortions $E$, assuming that they constitute true errors, are respectively $\sigma 1=1,155$ and $\sigma 2=1,140$.

For the needs of further verifications, five test objects were prepared. They are described by sets of a priori assumed explanatory variable values (Tab. 7). On this basis, the resulting model values were determined. Since such created values are not stressed by any disturbance, they are regarded as errorfree true values (TV). One should not interpret this quantity as a typical price (like $Y$ ). Price $\mathbf{Y}$ does not, however, precisely represent the value hidden behind it. 


\section{Table 5}

Vectors of parameters $\boldsymbol{X}$, of disturbances $\boldsymbol{E} 1, \boldsymbol{E} 2$

$\mathrm{X}:=\left(\begin{array}{c}10 \\ 1 \\ 2 \\ 3\end{array}\right) \mathrm{E} 1:=\left(\begin{array}{c}1 \\ 1 \\ -1 \\ -1 \\ -1 \\ 1 \\ 1 \\ -2 \\ 1\end{array}\right) \mathrm{E} 2:=\left(\begin{array}{c}1 \\ 1 \\ -1 \\ -1 \\ -1 \\ 1 \\ 1 \\ -2 \\ 1 \\ 1\end{array}\right)$

Source: own study.

Table 6

Vectors of simulated values of dependent variables (prices) $\mathbf{Y 1}$ (VB) and $\mathbf{Y} 2$ (VA) in particular suboptions

\begin{tabular}{cccccc}
\hline $\boldsymbol{Y 1}$ & $\boldsymbol{Y 2 1}$ & $\boldsymbol{Y 2 2}$ & $\boldsymbol{Y 2 3}$ & $\boldsymbol{Y 2 4}$ & $\boldsymbol{Y 2 5}$ \\
\hline 20 & 20 & 20 & 20 & 20 & 20 \\
25 & 25 & 25 & 25 & 25 & 25 \\
28 & 28 & 28 & 28 & 28 & 28 \\
22 & 22 & 22 & 22 & 22 & 22 \\
27 & 27 & 27 & 27 & 27 & 27 \\
25 & 25 & 25 & 25 & 25 & 25 \\
28 & 28 & 28 & 28 & 28 & 28 \\
24 & 24 & 24 & 24 & 24 & 24 \\
26 & 26 & 26 & 26 & 26 & 26 \\
& 26 & 29 & 32 & 35 & 38 \\
\hline
\end{tabular}

Source: own study.

Table 7

Characteristics of test objects and their model values

\begin{tabular}{|c|c|c|c|c|c|}
\hline \multirow{4}{*}{$\begin{array}{r}\text { number } \\
\text { of test } \\
\text { objects }\end{array}$} & \multicolumn{4}{|c|}{ A priori model parameters $\left(X^{T}\right)$} & \multirow{4}{*}{$\begin{array}{c}\text { Model value - true value } \\
\text { of the object }(\mathrm{TV}) \\
T V=A_{I N D} \cdot X\end{array}$} \\
\hline & 10 & 1 & 2 & 3 & \\
\hline & \multicolumn{4}{|c|}{ Evaluation of test objects $\left(A_{I N D}\right)$} & \\
\hline & Constant & Variable 1 & Variable 2 & Variable 3 & \\
\hline 1 & 1 & 1 & 1 & 4 & 25 \\
\hline 2 & 1 & 2 & 2 & 4 & 28 \\
\hline 3 & 1 & 3 & 3 & 4 & 31 \\
\hline 4 & 1 & 4 & 4 & 4 & 34 \\
\hline 5 & 1 & 5 & 5 & 4 & 37 \\
\hline
\end{tabular}

Source: own study.

In the course of the conducted calculations, the above model values were used as reference (control) values for the results of proper test object value estimations (understood as the potential unit values of real estate), obtained with use of individual test models $A$. 
The calculations were implemented by a typical procedure of the least squares method, with use of a linear model and taking into account stochastic component $\varepsilon$.

$$
Y=A \cdot X+\varepsilon
$$

Explanatory variable standardization was performed separately in each data set of every variant. This resulted in the evaluation of the highest values of test object variables, with figures exceeding the range of $(0,1)$.

The obtained results have been compiled in Tabs. 8, 9, 10:

Quality characteristics of particular test models

\begin{tabular}{lccc}
\hline & $\begin{array}{c}\text { Root Mean Squared } \\
\text { Error RMSE } \\
\text { of VA/VB Model }\end{array}$ & $\begin{array}{c}\text { Coefficient of } \\
\text { determination } \\
\text { Variant of model }\end{array}$ & $\begin{array}{c}\text { Proportion } \\
\text { coefficient } \\
U=\end{array}$ \\
\hline Basic VB & 1.348 & 0.843 & 1.000 \\
Alternative VA1 & 1.304 & 0.827 & 0.967 \\
Alternative VA 2 & 1.369 & 0.845 & 1.016 \\
Alternative VA 3 & 1.427 & 0.880 & 1.059 \\
Alternative VA 4 & 1.428 & 0.917 & 1.059 \\
Alternative VA 5 & 1.393 & 0.945 & 1.033 \\
\hline
\end{tabular}

Source: own study.

Results of estimations of test object values in the basic variant (VB)

\begin{tabular}{cccccccc}
\hline $\begin{array}{c}\text { No. of } \\
\text { test } \\
\text { object }\end{array}$ & Standardized assessments of object valuation & $\begin{array}{c}\text { Estimation of } \\
\text { values of test } \\
\text { objects }\end{array}$ & $\begin{array}{c}\text { RMSEIND } \\
\text { Average error } \\
\text { of estimated } \\
\text { value }\end{array}$ & $\begin{array}{c}\text { True error of } \\
\text { estimated value }\end{array}$ \\
\cline { 2 - 6 } & Constant & Variable 1 & Variable 2 & Variable 3 & & & \\
\hline 1 & 1 & -0.5 & -0.5 & 1.5 & 24.190 & 1.869 & -0.810 \\
2 & 1 & 0 & 0 & 1.5 & 26.910 & 1.362 & -1.090 \\
3 & 1 & 0.5 & 0.5 & 1.5 & 29.629 & 1.204 & -1.371 \\
4 & 1 & 1 & 1 & 1.5 & 32.348 & 1.507 & -1.652 \\
5 & 1 & 1.5 & 1.5 & 1.5 & 35.067 & 2.079 & -1.933 \\
\hline
\end{tabular}

Source: own study.

Table 10

Results of estimations of test object values in alternative variants (VA)

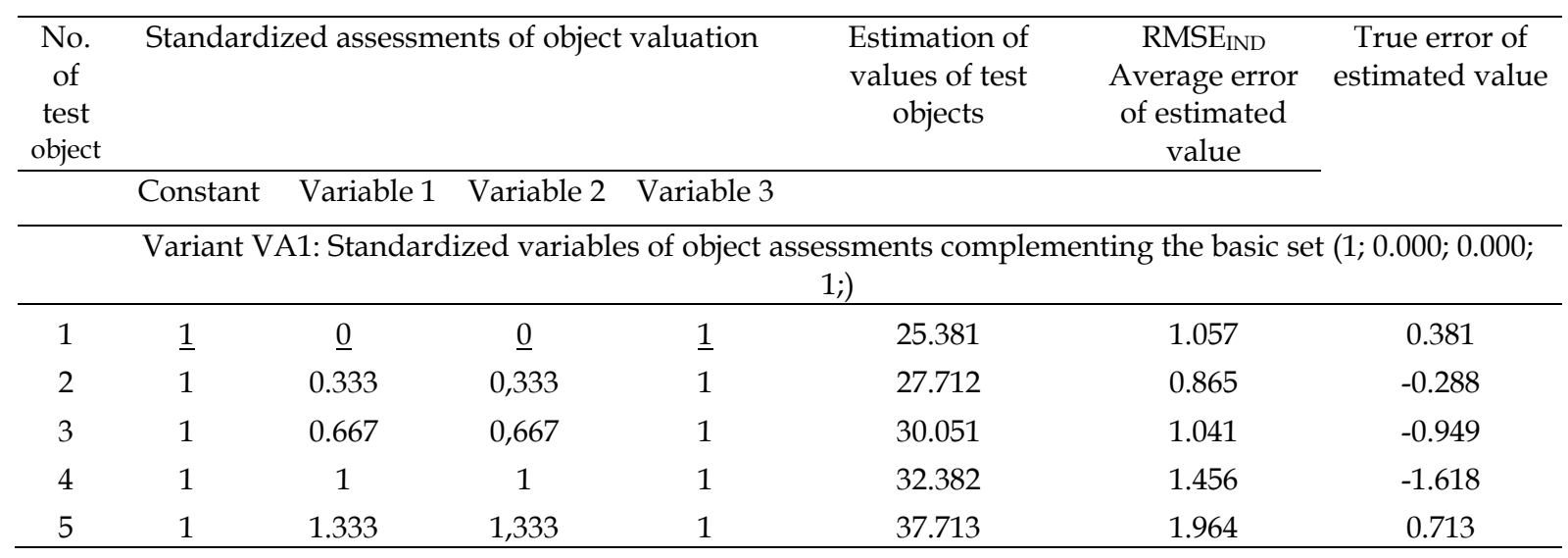




\begin{tabular}{|c|c|c|c|c|c|c|c|}
\hline & \multicolumn{7}{|c|}{$\begin{array}{l}\text { Variant VA2: Standardized variables of object assessments complementing the basic set }(1 ; 0.000 ; 0.000 ; \\
1 ;)\end{array}$} \\
\hline 1 & 1 & -0.5 & -0.5 & 1 & 25.539 & 1.424 & 0.539 \\
\hline 2 & $\underline{1}$ & $\underline{0}$ & $\underline{0}$ & $\underline{1}$ & 27.963 & 0.973 & -0.037 \\
\hline 3 & 1 & 0.5 & 0.5 & 1 & 30.393 & 0.993 & -0.607 \\
\hline 4 & 1 & 1 & 1 & 1 & 32.817 & 1.464 & -1.183 \\
\hline 5 & 1 & 1.5 & 1.5 & 1 & 35.240 & 2.102 & -1.760 \\
\hline \multicolumn{8}{|c|}{ Variant VA3: Standardized variables of object assessments complementing the basic set $(1 ; 0.5 ; 0.5 ; 1 ;)$} \\
\hline 1 & 1 & -0.5 & -0.5 & 1 & 25.095 & 1.839 & 0.095 \\
\hline 2 & 1 & 0 & 0 & 1 & 27.884 & 1.208 & -0.116 \\
\hline 3 & $\underline{1}$ & $\underline{0.5}$ & $\underline{0.5}$ & $\underline{1}$ & 30.681 & 0.950 & -0.319 \\
\hline 4 & 1 & 1 & 1 & 1 & 33.470 & 1.310 & -0.530 \\
\hline 5 & 1 & 1.5 & 1.5 & 1 & 36.259 & 1.974 & -0.741 \\
\hline \multicolumn{8}{|c|}{ Variant VA4: Standardized variables of object assessments complementing the basic set $(1 ; 1 ; 1 ; 1 ;)$} \\
\hline 1 & 1 & -0.5 & -0.5 & 1 & 24.268 & 1.977 & -0.732 \\
\hline 2 & 1 & 0 & 0 & 1 & 27.448 & 1.375 & -0.552 \\
\hline 3 & 1 & 0.5 & 0.5 & 1 & 30.638 & 0.981 & -0.362 \\
\hline 4 & 1 & $\underline{1}$ & $\underline{1}$ & 1 & 33.818 & 1.064 & -0.182 \\
\hline 5 & 1 & 1.5 & 1.5 & 1 & 36.997 & 1.547 & -0.003 \\
\hline \multicolumn{8}{|c|}{ Variant VA5: Standardized variables of object assessments complementing the basic set $(1 ; 1 ; 1 ; 1 ;)$} \\
\hline 1 & 1 & -0.333 & -0.333 & 1 & 23.709 & 1.884 & -1.291 \\
\hline 2 & 1 & 0 & 0 & 1 & 27.061 & 1.401 & -0.939 \\
\hline 3 & 1 & 0.333 & 0.333 & 1 & 30.419 & 1.034 & -0.581 \\
\hline 4 & 1 & 0.667 & 0.667 & 1 & 33.774 & 0.933 & -0.226 \\
\hline 5 & 1 & $\underline{1}$ & $\underline{1}$ & 1 & 37.125 & 1.169 & 0.125 \\
\hline
\end{tabular}

Source: own study.

On the basis of the comparative analysis of basic and alternative test models in Tab. 8, it can be concluded that the extension of the data set always has an unfavorable effect on the quality of the model related to this set. Similar conclusions can also be found in (HOZER et al. 2002, KALIBATAS et al. 2012 and BEAMONTE et al. 2013). However, attention ought to be paid to the detailed results in Tab. 9 and 10. Average errors of value estimation for particular test objects are always better (lower) in alternative estimation variants. In Tab. 10, underlining indicates the identicalness of the estimated test object variable assessments and the assessments of analogous variables of objects complementing the matrix of explanatory variables of the test model in the basic variant. Moreover, the values of the available true errors (understood as the differences between particular estimations in relation to deterministically determined error-free model values - likely to be controlled only in simulation models) are also lower. Particular attention ought to be paid to the observation that, in reference to test models of characteristics exceeding the ranges of explanatory variable values occurring in respective $A$ matrices, the attachment of a record with characteristics similar to those of the given test object to the set of observations creating the given model demonstrates the minimization of the average error of value estimation of this object. This is illustrated more clearly in Tab. 11, where the proper proportions of mean squared errors have been compiled. Proportions $U$ of root mean squared errors of models (RMSE):

$$
U=R M S E_{V A}: R M S E_{V B}
$$

which also happens to be shown in Tab. 8, indicates the degree of quality adjustment (expressed by error RMSE) of the alternative model, which includes the extension of the basic $\mathbf{1 1}, \mathbf{A 1}$ model set by subsequent, additional records (from Tab.7). However, respective individual root mean squared errors of models (RMSE) of individual test object value estimations, in alternative variants (VA) in relation to analogous errors from the basic variant $(\mathrm{VB})$, were juxtaposed in proportions $U_{I N D}$ :

$$
U_{I N D}=R M S E_{I N D V A}: R M S E_{I N D V B}
$$


This illustrates the estimation change of mean errors $R M S E_{I N D}$ for every estimation of one out of five test objects in the individual variants of the alternative model relative to the corresponding error in estimation on the basis of the basic model. $R M S E_{I N D}$ errors were set out as errors of linear functions of parameters $X$ and variables describing the specific test object. Underlining in Tab. 11 indicates the locally lowest values of proportion coefficients $U_{I N D}$ (and also $U_{I N D}: U$ ) showing a strong relationship between the cases of minimizing proportion coefficients $U_{I N D}$ and cases of the identicalness of values of explanatory variable assessments of test objects with the assessments of analogous variables of objects complementing matrix of explanatory variables of the test model in the basic variant.

Results of estimations of test objects in alternative variants (VA)

Table 11

\begin{tabular}{ccccc}
\hline No. & & & & \\
of & Standardized assessments of object valuation & Proportion & Proportion & \\
test & & coefficient & coefficient & $U_{I N D}: U$ \\
object & $R M S E_{V A}:$ & $U_{I N D}=$ & \\
& $R M S E_{I N D V A}:$ & \\
\hline
\end{tabular}

\begin{tabular}{cccc}
\hline $\begin{array}{c}\text { Constan } \\
\mathrm{t}\end{array}$ & $\begin{array}{c}\text { Variabl } \\
\mathrm{e} 1\end{array}$ & Variable 2 & Variable 3 \\
\end{tabular}

Variant VA1: Standardized variables of object assessments complementing the basic set $(1 ; 0.000 ; 0.000$;

\begin{tabular}{|c|c|c|c|c|c|c|c|}
\hline \multicolumn{8}{|c|}{ 1;) } \\
\hline 1 & 1 & 0 & 0 & 1 & \multirow[t]{5}{*}{0.967} & $\underline{0.566}$ & $\underline{0.585}$ \\
\hline 2 & 1 & 0.333 & 0.333 & 1 & & 0.635 & 0.657 \\
\hline 3 & 1 & 0.667 & 0.667 & 1 & & 0.865 & 0.894 \\
\hline 4 & 1 & 1 & 1 & 1 & & 0.966 & 0.999 \\
\hline 5 & 1 & 1.333 & 1.333 & 1 & & 0.945 & 0.977 \\
\hline \multicolumn{8}{|c|}{ Variant VA2: Standardized variables of object assessments complementing the basic set $(1 ; 0.00 ; 0.00 ; 1 ;)$} \\
\hline 1 & 1 & -0.5 & -0.5 & 1 & \multirow[t]{5}{*}{1.016} & 0.762 & 0.750 \\
\hline 2 & 1 & $\underline{0}$ & $\underline{0}$ & 1 & & $\underline{0.714}$ & $\underline{0.703}$ \\
\hline 3 & 1 & 0.5 & 0.5 & 1 & & 0.825 & 0.812 \\
\hline 4 & 1 & 1 & 1 & 1 & & 0.971 & 0.957 \\
\hline \multirow[t]{2}{*}{5} & 1 & 1.5 & 1.5 & 1 & & 1.011 & 0.996 \\
\hline & \multicolumn{7}{|c|}{ Variant VA3: Standardized variables of object assessments complementing the basic set $(1 ; 0.5 ; 0.5 ; 1 ;)$} \\
\hline 1 & 1 & -0.5 & -0.5 & 1 & \multirow[t]{5}{*}{1.059} & 0.984 & 0.929 \\
\hline 2 & 1 & 0 & 0 & 1 & & 0.887 & 0.838 \\
\hline 3 & 1 & $\underline{0.5}$ & $\underline{0.5}$ & 1 & & $\underline{0.789}$ & $\underline{0.745}$ \\
\hline 4 & 1 & 1 & 1 & 1 & & 0.869 & 0.821 \\
\hline \multirow[t]{2}{*}{5} & 1 & 1.5 & 1.5 & 1 & & 0.949 & 0.897 \\
\hline & \multicolumn{7}{|c|}{ Variant VA4: Standardized variables of object assessments complementing the basic set $(1 ; 1 ; 1 ; 1 ;)$} \\
\hline 1 & 1 & -0.5 & -0.5 & 1 & 1.059 & 1.058 & 0.999 \\
\hline 2 & 1 & 0 & 0 & 1 & & 1.010 & 0.953 \\
\hline 3 & 1 & 0.5 & 0.5 & 1 & & 0.815 & 0.769 \\
\hline 4 & 1 & $\underline{1}$ & $\underline{1}$ & 1 & & $\underline{0.706}$ & $\underline{0.666}$ \\
\hline \multirow[t]{2}{*}{5} & 1 & 1.5 & 1.5 & 1 & & 0.744 & 0.702 \\
\hline & \multicolumn{7}{|c|}{ Variant VA5: Standardized variables of object assessments complementing the basic set $(1 ; 1 ; 1 ; 1 ;)$} \\
\hline 1 & 1 & -0.333 & -0.333 & 1 & 1.033 & 1.008 & 0.975 \\
\hline 2 & 1 & 0 & 0 & 1 & & 1.029 & 0.995 \\
\hline 3 & 1 & 0.333 & 0.333 & 1 & & 0.859 & 0.831 \\
\hline 4 & 1 & 0.667 & 0.667 & 1 & & 0.619 & 0.599 \\
\hline 5 & 1 & $\underline{1}$ & $\underline{1}$ & 1 & & $\underline{0.562}$ & $\underline{0.544}$ \\
\hline
\end{tabular}

Source: own study. 
The proportion $U_{I N D}: U$ is independent in relation to $R M S E_{V A}$ and $R M S E_{V B}$, and thus demonstrates the impact of the set $A$ extension procedure itself in the alternative model in relation to a set $A$ and the basic model, as well as the similarity relationship between the object complementing the set and the test model. However, similarity in this case is understood as a simple relation of variable values describing both compared elements. The proportion $U_{I N D}: U$ remains closely adjusted to the dissimilarity of the element complementing the basic set $A$ with the estimated test model (measured by Euclidean distance), which is illustrated by the contents of Tab. 12 .

Apart from the conclusions described above, the presented examples of estimations, due to their simulative nature, enable additional characteristic features of calculations to be revealed with the use of the least squares method, which has its restrictions, as do the majority of methods which are possible to apply. Due to having control over the adopted assumptions (shown in Tabs. 1-7), theoretical model values that were treated as error-free, were determined for particular test objects, which, if transformed into true cases, can be treated as the equivalent of true values. These values have been presented in Tab. 7. These are unattainable control elements in true conditions, additionally revealing how relevant or irrelevant the results of a particular performed estimation are. The analysis of qualities marked as true errors proves that, despite proper accounting of the estimations carried out, and despite their theoretical improvement thanks to the applied complements of the reference set of transactions, one does not have full control of the relevance of calculations. Openly admitted distortion $E$ of hypothetical transaction prices $Y$, whose possible decrease would make the results coherent, is to be blamed for such a phenomenon. Relatively large values of distortions $E$ were intended to bring the performed simulation examples closer to the real conditions in which these distortions are unknown, and the assumption that they can take on minimized quantities is unacceptable.

Table 12

Outcomes of result improvement of test object estimation in relation to relative similarity

\begin{tabular}{|c|c|c|c|c|c|c|c|}
\hline \multirow[t]{2}{*}{$\begin{array}{l}\text { No. } \\
\text { of } \\
\text { test } \\
\text { object }\end{array}$} & Standar & ized assess & ents of objec & valuation & $U_{I N D}: U$ & $\begin{array}{l}\text { Euclidean distance } \\
\text { relative to } \\
\text { complementing } \\
\text { object }\end{array}$ & \multirow{2}{*}{$\begin{array}{c}\text { Pearson } \\
\text { product- } \\
\text { moment } \\
\text { correlation } \\
\text { coefficient }\end{array}$} \\
\hline & $\begin{array}{c}\text { Constan } \\
t\end{array}$ & Variable 1 & Variable 2 & Variable 3 & & & \\
\hline
\end{tabular}

1;)

\begin{tabular}{cccccccc}
\hline 1 & 1 & 0 & 0 & 1 & 0.585 & 0.000 & 0.939 \\
2 & 1 & 0.333 & 0.333 & 1 & 0.657 & 0.471 & \\
3 & 1 & 0.667 & 0.667 & 1 & 0.894 & 0.943 & \\
4 & 1 & 1 & 1 & 1 & 0.999 & 1.414 & \\
5 & 1 & 1.333 & 1.333 & 1 & 0.977 & 1.885 & \\
\hline \multicolumn{7}{l}{ Variant VA2: Standardized variables of object assessments complementing the basic set $(1 ; 0.00 ; 0.00 ;$}
\end{tabular}

1;)

\begin{tabular}{cccccccc}
\hline 1 & 1 & -0.5 & -0.5 & 1 & 0.750 & 0.471 & 0.957 \\
2 & 1 & $\underline{0}$ & $\underline{0}$ & 1 & 0.703 & 0.000 & \\
3 & 1 & 0.5 & 0.5 & 1 & 0.812 & 0.472 & \\
4 & 1 & 1 & 1 & 1 & 0.957 & 0.943 & \\
5 & 1 & 1.5 & 1.5 & 1 & 0.996 & 1.414 & \\
\hline
\end{tabular}

Variant VA3: Standardized variables of object assessments complementing the basic set $(1 ; 0.5 ; 0.5 ; 1 ;)$

\begin{tabular}{cccccccc}
\multicolumn{7}{c}{ Variant } & A3: Standardized variables of object assessments complementing the basic set $(1 ; 0.5 ; 0.5 ; 1 ;)$ \\
\hline 1 & 1 & -0.5 & -0.5 & 1 & 0.929 & 0.943 & 0.984 \\
2 & 1 & 0 & 0 & 1 & 0.838 & 0.472 & \\
3 & 1 & $\underline{0.5}$ & $\underline{0.5}$ & 1 & 0.745 & 0.000 \\
4 & 1 & 1 & 1 & 1 & 0.821 & 0.471 \\
5 & 1 & 1.5 & 1.5 & 1 & 0.897 & 0.942 \\
\hline
\end{tabular}

Variant VA4: Standardized variables of object assessments complementing the basic set $(1 ; 1 ; 1 ; 1 ;)$
11
$-0.5$
$-0.5$
1
0.999
1.414
0.950 


\begin{tabular}{ccccccc}
2 & 1 & 0 & 0 & 1 & 0.953 & 0.943 \\
3 & 1 & 0.5 & 0.5 & 1 & 0.769 & 0.471 \\
4 & 1 & $\underline{1}$ & $\underline{1}$ & 1 & 0.666 & 0.000 \\
5 & 1 & 1.5 & 1.5 & 1 & 0.702 & 0.471 \\
\hline \multicolumn{7}{c}{ Variant VA5: Standardized variables of object assessments complementing the basic set $(1 ; 1 ; 1 ; 1 ;)$} \\
\hline 1 & 1 & -0.333 & -0.333 & 1 & 0.975 & 1.885 \\
2 & 1 & 0 & 0 & 1 & 0.995 & 1.414 \\
3 & 1 & 0.333 & 0.333 & 1 & 0.831 & 0.942 \\
4 & 1 & 0.667 & 0.667 & 1 & 0.599 & 0.471 \\
5 & 1 & $\underline{1}$ & $\underline{1}$ & 1 & 0.544 & 0.000 \\
\hline
\end{tabular}

Source: own study.

\section{Conclusions}

Despite the critical nature of the above remarks on the problem of controlling the relevance of calculations, the presented results prove the significance of similarity occurring between set components of explanatory variables, serving as the base for the development of the model, in estimating the value of real estate by using the least squares method. In contrast to common assessments, the model of explained variables, based on a set of explanatory values and taking into account the relatively narrow rating scale of these variables, sometimes leads to worse results of estimations of tested real estate properties (measured by average errors RMSE and RMSE $E_{I N D}$ ) than an analogous model containing an element having similar values of explanatory variables to the characteristics of the property being estimated. The set of root mean square errors of models RMSE (Tab. 8) proves that coherence between the assessments of market features of real estate in a reference set decreases the quality of extended models.

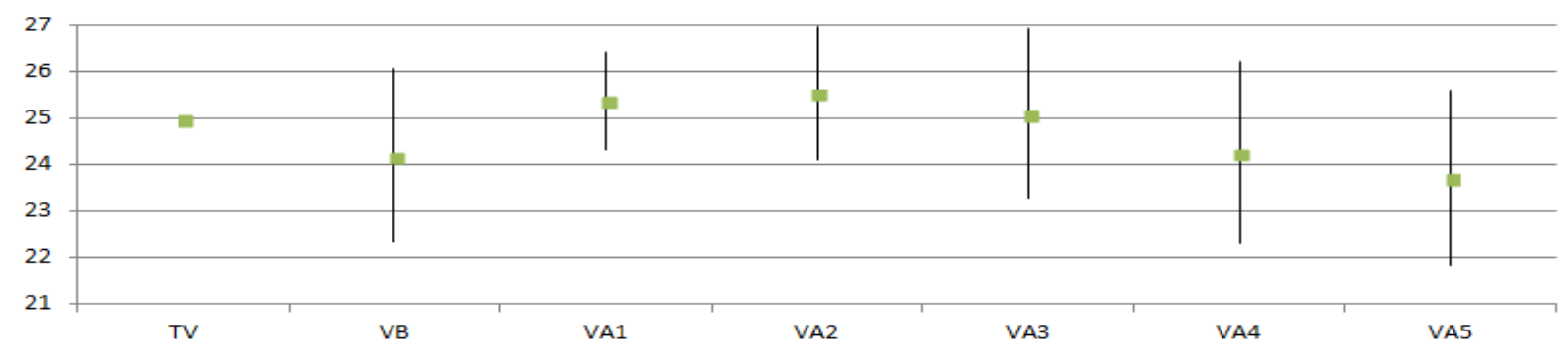

Fig. 1. Results of variant (VB/VA) appraisal of tested object value No. 1 in relation to the true value (TV). Source: own study.

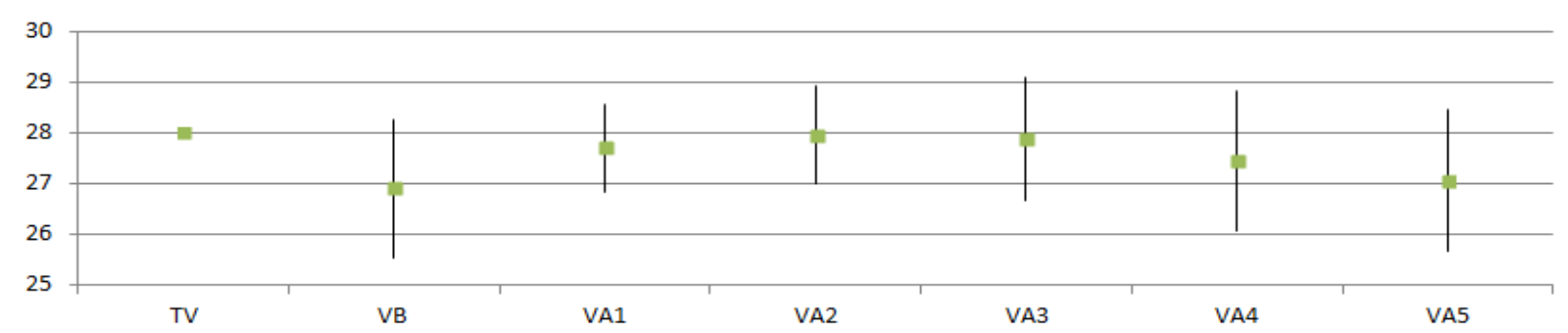

Fig. 2. Results of variant (VB/VA) appraisal of test object value No. 2 in relation to true value (TV). Source: own study

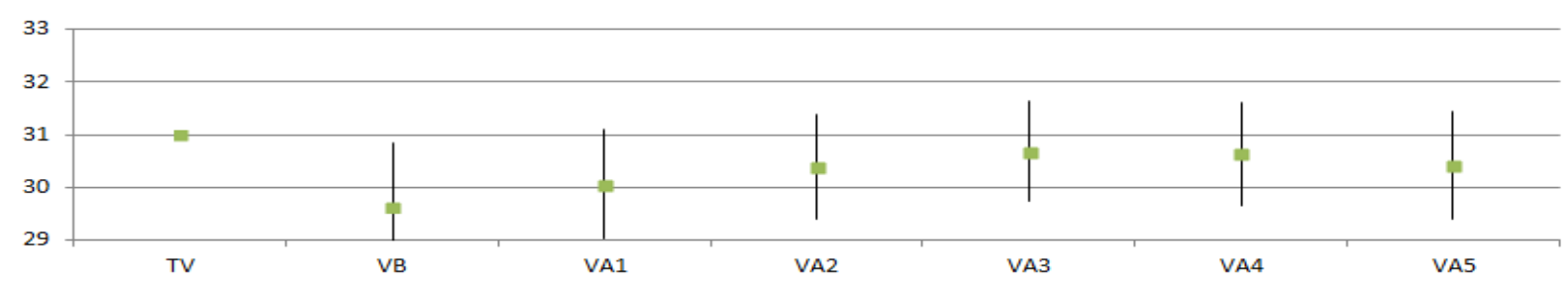


Fig. 3. Results of variant (VB/VA) appraisal of test object value No. 3 in relation to true value (TV). Source: own study.

Dissimilarity of test objects in terms of the assessment of selected characteristics relative to properties in a reference set, thus the necessity of estimating the value of an explained variable for the system of assessments (explanatory variables) imposing extrapolation beyond the rating scale applied to the collected reference set, leads to inaccurate estimations measured by the average error RMSEIND of estimated value (e.g. the first and last estimation in Tab. 9). The quality of this set is radically improved by the enlargement of a reference set by an element similar to the estimated object by the quantities of explanatory variables describing it (Tab. 10). As it was shown by the conducted research, besides the improvement of statistically valuated correctness of estimation, the erroneousness of such an estimation, measured in relation to the true value, is minimized by such complementing of the set of transactions on the basis of which the price model is developed. This is well illustrated by the graphs shown above and below (Fig. 1-5).

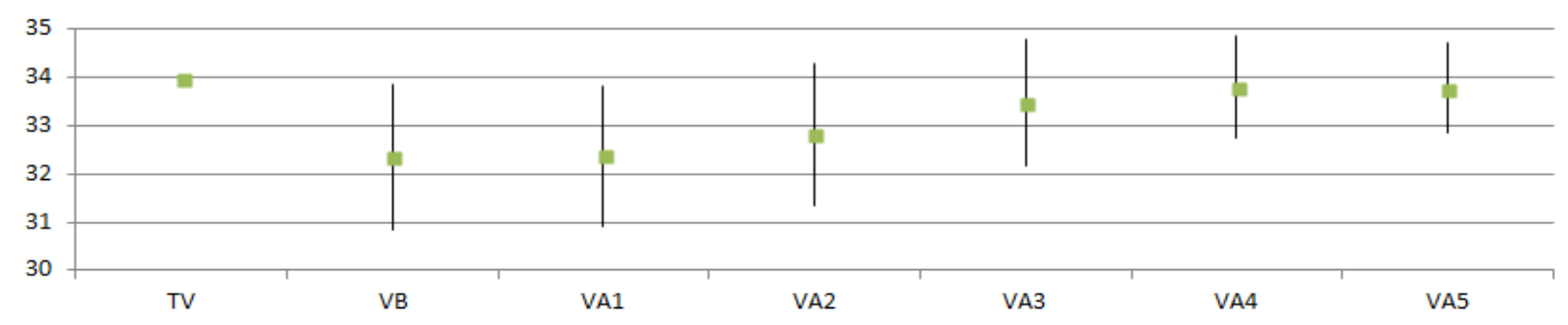

Fig. 4. Results of variant (VB/VA) appraisal of test object value No. 4 in relation to the true value (TV). Source: own study.

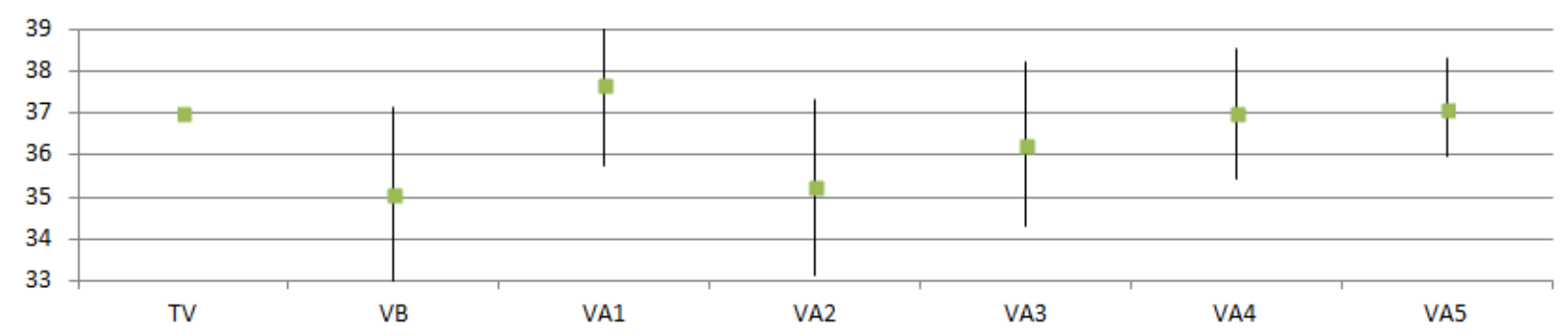

Fig. 5. The results of variant (VB/VA) appraisal of test object value No. 5 in relation to the true value (TV). Source: own study.

However, one must keep in mind that the presented tests are based on sets of extremely small numbers, the application of a differential method, as well as basing the calculations on a simulation example (where all essential reference elements are defined), make it possible to pose a working hypothesis that the drawn conclusions can be considered as relevant.

The results of the conducted test should be regarded as a warning against the temptation to treat statistical methods as a universal tool, operating automatically, also in reference to poorly recognizable phenomena, which real estate are regarded as. They also incline one to resign from the appraisal of property on the basis of a model developed with the use of information on transactions referring to dissimilar properties or bearing little resemblance to the valuated object, even if these properties meet the location condition described in Art. 161.2 of the Act of Real Estate Management ("The value of representative real estate is determined with the use of property transaction prices on the territory of administrative district"). It is also worth bearing in mind that, despite the nature of statistical methods benefiting from the fact of the dissimilarity of objects whose characteristics and transaction prices are used to develop a prices/values model, the similarity, even of a part, of the elements of this model to the valuated object prejudge the acceptable estimation accuracy characteristics and allow the estimated value to be closer to the actual value.

It is worth mentioning here that, for the purpose of property appraisal, price/value models should be developed on the basis of attributes having a real association with the market features of the properties themselves ( $\$ 4.1$ ROZPORZĄDZENIE ... 2004). In Polish legal conditions, acc. to (Art. 149 USTAWA ... 1997) and ( $\$ 4.2$ ROZPORZĄDZENIE ... 2004), determining the market value of real estate with the use of statistical methods was established as a part of the comparative approach. Thus, in relation 
to determining the market values of properties with the use of statistical methods, the principles of econometrics cannot be used exclusively, yet the rules from the Art. 153.1 of the Act of Real Estate Management (USTAWA ... 1997) must be respected („The comparative approach is applied when the prices and features of properties similar to valuated property are known"). The restriction of conditions for the application of statistical methods to estimate a property value will function until an appraisal method corresponding to the appraisal performed by so-called "desk appraisal" appears in Polish legislation.

\section{References}

BARAŃSKA A., 2004, Wybór cech nieruchomości do modelowania matematycznego wartości rynkowej na przykładzie kilku baz nieruchomości gruntowych, (Selection of Real Estate Features for Mathematical Modelling of the Market Value Exemplified by Several Databases of ground Properties) (in Polish), Geodezja, Vol. 10. No. 1. pp. 31-38.

Beamonte A., Gargallo P., Salvador M.J., 2013, Retrospective Analysis of the Dwelling Price by Means of STAR Models with Neighborhood Effects, Journal of Real Estate Research, Vol. 35, No. 2, pp. $173-197$

Benjamin J. D., RANDAll S. GutTery R. S., SiRmans C. F., 2004, Mass Appraisal: An Introduction to Multiple Regression Analysis for Real Estate Valuation, Journal of Real Estate Practice and Education, Vol. 7, No. 1, pp. 65-77.

Beracha E. BABAJIDE WinTOKI M., 2013, Forecasting Residential Real Estate Price Changes from Online Search Activity, Journal of Real Estate Research, Vol. 35, No. 3, pp. 283-312.

BITNER A., 2007, Konstrukcja modelu regresji wielorakiej przy wycenie nieruchomości (Construction of a Multiple Regression Model for the Valuation of Real Estate) (in Polish), Acta Scientiarum Polonorum,Administratio Locorum, No. 6(4), pp. 59-66.

HOZER J., KOKOT S., KUŹMIŃSKI W., 2002, Metody analizy statystycznej rynku w wycenie nieruchomości, (Methods of Statistical Market Analysis in Real Estate Valuation) (in Polish), Wyd. PFSRM,. Warszawa.

Kalibatas D., ZaVADSKas E.K., KalibatienE D., 2012, A Method of Multi-Attribute Assessment Using Ideal Alternative: Choosing an Apartment with Optimal Indoor Environment, International Journal of Strategic Property Management, Vol. 16, Issue 3, pp. 338-353.

KIEHELÄ S., FALKENBACH H., 2014, Modelling and Forecasting Central Helsinki Office Rents, International Journal of Strategic Property Management, Vol. 18, Issue 3, pp. 292-306.

MeSZEK W., 2013, Property Valuation Under Uncertainty. Simulation vs Strategic Model, International Journal of Strategic Property Management, Vol. 17, issue 3, pp. 79-92.

PAWLAK Z., 1983, Systemy informacyjne. Podstawy teoretyczne, (Information Systems. Theoretical Basis) (in Polish), WNT, Warszawa.

Rozporządzenie Rady Ministrów z dnia 21 września 2004 r. w sprawie wyceny nieruchomości $i$ sporządzania operatu szacunkowego (Dz.U. 2004 nr 207 poz. 2109 z późniejszymi zmianami). (Regulation of the Council of Ministers of 21 September 2004 on the valuation of the property and the preparation of the valuation report, Journal of Laws 2004, No. 207, item 2109, as amended).

Ustawa z dnia 21 sierpnia 1997 o gospodarce nieruchomościami r. (Dz. U. z 2015r. poz. 782) (The Act of 21 August 1997 on Real Property Management, Journal of Laws 1997, No. 115, item 741 as amended).

ZyGA J., 2011, Definicja podobieństwa nieruchomości dla potrzeb ich wyceny (Similarity Definition for Real Estate Appraisal); Rzeczoznawca Majątkowy, 72 (4/2011), pp. 33-35.

ZYGA J., 2012, Istota podobieństwa w procedurach wyceny nieruchomości (Essence of Similarity in Real Estate Appraisal Procedures) (in Polish), Rzeczoznawca Majątkowy, 75 (3/2012), pp. 22-26. 